\title{
Research and development on high burnup HTGR fuels in JAEA
}

\author{
Shohei UETA*, Naoki MIZUTA*, Koei SASAKI*, Nariaki SAKABA*, \\ Hirofumi OHASHI* and Xing L. YAN* \\ *Japan Atomic Energy Agency \\ 4002 Narita-cho, Oarai-machi, Higashiibaraki-gun Ibaraki 311-1393, Japan \\ E-mail: ueta.shohei@jaea.go.jp
}

Received: 5 November 2019; Revised: 26 December 2019; Accepted: 4 February 2020

\begin{abstract}
JAEA has been progressing to design HTGR fuels for not only small-type practical HTGRs but also VHTR proposed in GIF which can be utilized for various purposes with high-temperature heat at 750 to $950{ }^{\circ} \mathrm{C}$. To increase economy of these HTGRs, JAEA has been upgrading the design method for the HTGR fuel, which can maintain their integrities at the burnup of three to four times higher than that of the conventional HTTR fuel. Design principles and specifications of various concepts of the high burnup HTGR fuels designed by JAEA are reported. As the latest results on post-irradiation examinations of the high burnup HTGR fuel progressing in a framework of international collaboration with Kazakhstan, irradiation shrinkage rate of the fuel compact as a function of fast neutron fluence was obtained at around $100 \mathrm{GWd} / \mathrm{thm}$. Furthermore, the future R\&Ds needed for the high burnup HTGR fuel are described based on these experimental results.
\end{abstract}

Keywords : HTGR, Fuel, High burnup, Coated fuel particle, Fuel compact

\section{Introduction}

Japan Atomic Energy Agency (JAEA) has been progressing to design various concepts of the high temperature gascooled reactor (HTGR) fuels for not only small-type practical HTGRs but also VHTR proposed in Generation IV International Forum (GIF) which can be utilized for various purposes with high-temperature heat at 750 to $950{ }^{\circ} \mathrm{C}$ (OECD Nuclear Energy Agency, 2012). Specification of the fuel for each HTGR is summarized in Table 1.

High Temperature Engineering Test Reactor (HTTR) is a research reactor constructed at Oarai Research Institute of JAEA (Saito, 1994). HTTR employs so-called pin-in-block type fuel element consisting of fuel rods and hexagonal graphite block. TRISO (Tri-structural isotropic)-coated fuel particle (CFP) with 12 kinds of low enriched uranium dioxide ( $\mathrm{UO}_{2}$; 3.4 to $9.9 \%$ of uranium $235,6 \%$ in average) fuel kernel is employed to attain the burnup of $22 \mathrm{GWd} /$ tonheavy-metal (thm) in average and $33 \mathrm{GWd} / \mathrm{thm}$ in maximum. A characteristic specification of the HTTR fuel is a larger

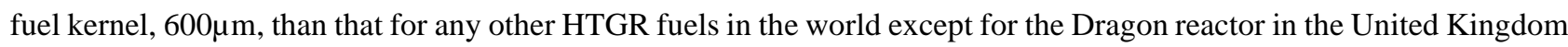
(Howard, 1978). This TRISO-CFP is dispersed in fuel compact with graphite and carbonized resin mixture matrix.

HTR50S is a small-sized practical HTGR developed by JAEA (Ohashi, 2011 and Goto, 2014). HTR50S has a concept to attain higher burnup of $100 \mathrm{GWd} / \mathrm{thm}$ (in maximum) than that of HTTR, which employs so-called the extended burnup (EBU) TRISO-CFP, consisting of a smaller $\mathrm{UO}_{2}$ kernel, thicker buffer and silicon carbide (SiC) coating layers than those of HTTR type one to reduce probability of CFP failure due to not only kernel migration but also internal gas pressure as described below. HTR50S also employs pin-in-block type fuel element.

GTHTR300 (Kunitomi, 2004) was developed as VHTR proposed by GIF. This reactor building employs a confinement structure as well as High Performance Commercial (HPC) HTGR. GTHTR300 also adopts high burnup TRISO-CFP targeting at $140 \mathrm{GWd} /$ thm in average and $155 \mathrm{GWd} /$ thm in maximum. One of characteristic points of this fuel is larger diameter of TRISO-CFP than any other HTGR in the world by adopting thicker buffer layer to prevent failure due to the internal gas pressure and kernel migration. Another is the monolithic fuel rod made with graphite matrix, in spite of the conventional one consisting of the fuel compact with graphite matrix and graphite sleeve, to 
enhance heat removal capability and increase power density of the reactor core. The height of fuel compact for GTHTR300 is settled more than that for the HTTR from the perspectives of the active length per a fuel rod nearly 1000 $\mathrm{mm}$ (i.e., $83 \mathrm{~mm} \times 12 \mathrm{pcs}$ ) and the productivity of the fuel compact (Katanishi, 2004).

Table 1 Specifications of HTGR fuels developed by JAEA.

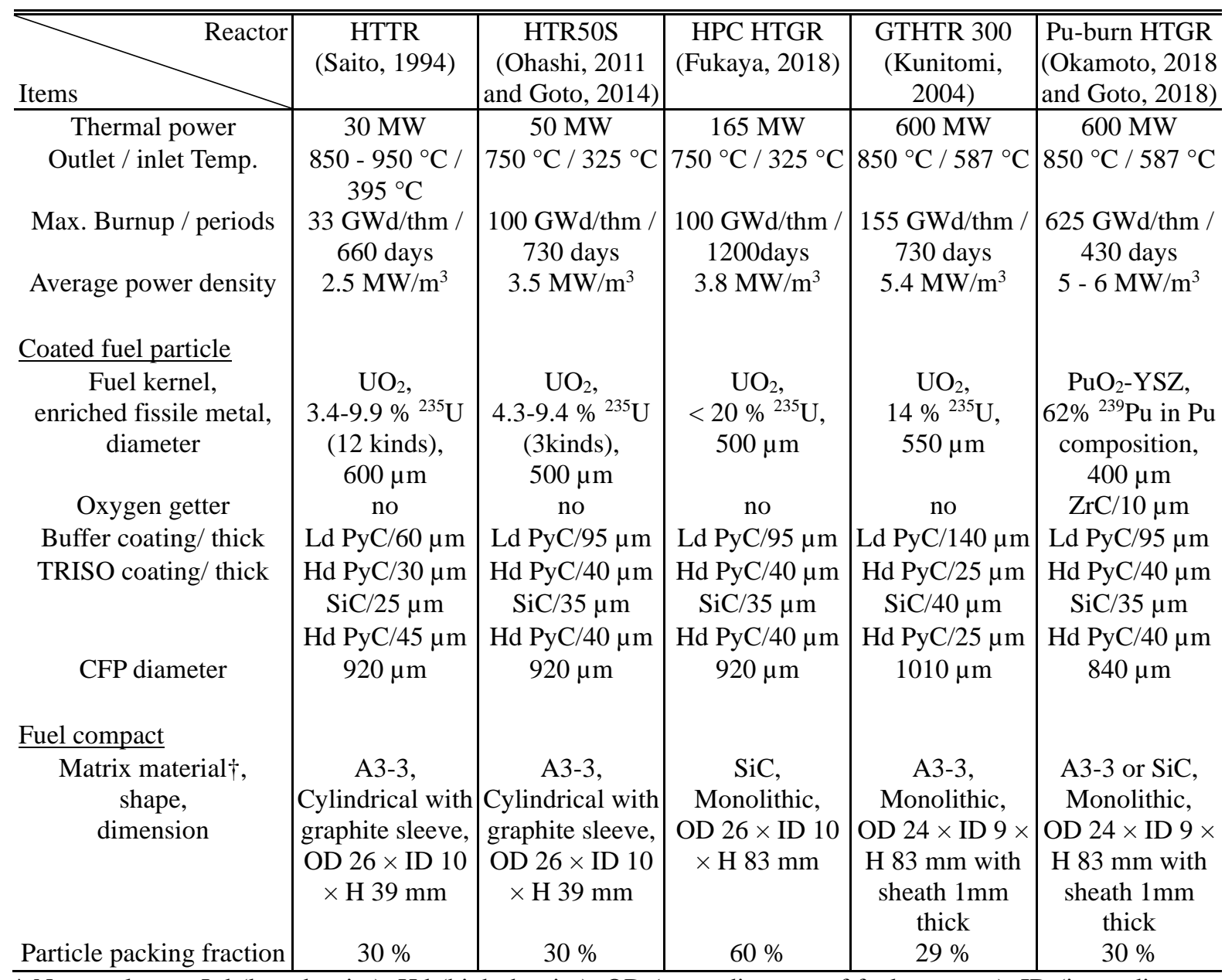

* Nomenclature; Ld (low density), Hd (high density), OD (outer diameter of fuel compact), ID (inner diameter of fuel compact), $\mathrm{H}$ (height of fuel compact).

† A3-3 means the mixture of $64 \mathrm{wt} \%$ of natural graphite, $16 \mathrm{wt} \%$ of petroleum graphite and $20 \mathrm{wt} \%$ of phenol resin (the value means weight percent before carbonization).

HPC HTGR is also a small-sized HTGR which is being concepted by JAEA (Fukaya, 2018). HPC HTGR will be adopted same TRISO-CFP to be used by $100 \mathrm{GWd} /$ thm in maximum as that for HTR50S. In addition, as a characteristic feature of HPC HTGR, the monolithic fuel rod made with SiC matrix is adopted in order to enhance an extreme safety against in-core oxidation accident. This SiC-matrixed fuel compact is being developed by JAEA to establish fabrication methods and to reveal thermal and mechanical properties under the irradiation (Mizuta, 2019). The U.S. has also been developing SiC-matrix fuel incorporating TRISO-CFP, including a patent for the U.S. concept (Venneri, 2016). This may provide an opportunity for international collaboration between Japan and the U.S. on advanced TRISO-CFP concepts to provide even higher levels of inherent safety and defense-in-depth.

Furthermore, plutonium (Pu)-burner HTGR is proposed to reduce Pu inventory by combustion using the inherently safe HTGR as focused on a super-safe nuclear system after the Fukushima-Daiichi Nuclear Power Plant Accident (Okamoto, 2018). In order to burn plutonium efficiently and in large quantities, Pu-burner HTGR targets a burnup of 10 times or more than that of ordinary uranium fuel of $500 \mathrm{GWd} / \mathrm{thm}$ (Fukaya, 2014). In addition, TRISO-CFP fabrication also had been confirmed to be high-reliability, i.e., 1/100 times smaller damage ratio over the conventional TRISO-CFP fabrication, through HTTR operation (Ueta, 2011). Therefore, so-called 3S-TRISO, i.e., TRISO-CFP with 
Safety, Security and Safeguards, is developed for the Pu-burner HTGR. This fuel employs yttria stabilized zirconia (YSZ), which is chemically inactive from the viewpoint of not only safety at the time of direct disposal but also nuclear nonproliferation (Kuramoto, 2003), as an inert matrix of plutonium dioxide $\left(\mathrm{PuO}_{2}\right)$ fuel kernel, thereby strengthening nuclear proliferation resistance by inert fuelization. Furthermore, zirconium carbide $(\mathrm{ZrC})$ is combined to suppress the rise in internal pressure of CO gas, which is the main cause of internal pressure failure during irradiation.

This paper describes the outline, latest results and future plan of the research and development (R\&D) on so-called "the high burnup fuel” for the HTGRs designed by JAEA as mentioned above. The meaning of this high burnup fuel consists of two parts; one is the upgraded TRISO-CFP for high burnup use, another the fuel compact with graphite matrix whose irradiation performance under high burnup condition is revealed.

For the former, historically Germany and the United States have achieved in 1980s the high burnups of the TRISOCFP with high enriched ${ }^{235} \mathrm{U}$ (16.7 and $19.9 \%$ ) for the AVR (Arbeitsgemeinschaft Versuchsreaktor) and the Fort St. Vrain reactors at around 120 and $150 \mathrm{GWd} / \mathrm{thm}$, respectively (IAEA, 1997). On the other hand, in 1990s, Japan has established the advanced and commercialized fabrication technologies of the HTTR fuel. Japan has employed the oncethrough coating technology, i.e., four layers are coated at once without unloading/loading of the fuel particle batch, which was also used in Germany (Sawa, 1999). In addition, conditions of the coating and compaction processes have been modified and optimized (Minato, 1997), then it was concluded that quality of the commercially-manufactured HTTR fuel achieved the highest level in the world (Ueta, 2011). In this study, to apply this HTTR fuel fabrication technology for the high burnup fuel enhancing economical features of HTGRs as proposed above by JAEA, we have been upgrading the design method for the TRISO-CFP which can maintain their integrities at the burnup of three to four times higher than that of the conventional HTTR fuel, $33 \mathrm{GWd} / \mathrm{thm}$ as the design limit.

For the latter, as the latest results on post-irradiation examinations (PIEs) of the fuel compact including the EBU TRISO-CFP progressing in a framework of international collaboration with Kazakhstan, irradiation shrinkage rate of this fuel compact was obtained at around $100 \mathrm{GWd} / \mathrm{thm}$. Furthermore, the future R\&Ds needed for the high burnup HTGR fuel are described based on these experimental results.

\section{Design principles of JAEA's high burnup HTGR fuel 2.1 Design principles}

Retentiveness of fission products (FPs) within the TRISO-CFP is important in the fuel safety design to keep their releases to the primary coolant below an acceptable level. From this viewpoint, JAEA settles the basic design criteria for the fuel as followings (Saito, 1994);

1) As-fabricated fuel failure fraction shall be minimized.

2) Significant additional failure shall be avoided during the operation. The followings meet this criterion;

- $\quad$ Fuel shall not fail systematically under normal operating condition.

- $\quad$ Fuel temperature shall be limited below $1600{ }^{\circ} \mathrm{C}$ under anticipated occasional occurrences (AOOs).

- $\quad$ Fuel burnup is limited in the basis of the results of the irradiation test.

Since HTTR is the first HTGR constructed in Japan, a reactor pressure vessel and major primary cooling system such as primary pressurized water cooler and intermediate heat exchanger are located inside a containment vessel. Therefore, as-fabricated fuel failure fraction is limited lower than $0.2 \%$ from the viewpoint of limit of off-site exposure during the normal operation (Saito, 1994). Also, in the safety design of the HTTR fuel, two systematic failure modes of the HTTR fuel are defined; kernel migration (Lindemer, 1974) and corrosion of SiC coating by palladium (Minato, 1990), against which the intactness of the fuel were demonstrated through the irradiation test. Furthermore, fuel burnup is limited to $33 \mathrm{GWd} / \mathrm{thm}$ in maximum in the basis of the results of irradiation tests (Hayashi, 1989).

For GTHTR300, HTR50S and HPC HTGR, a confinement structure will be adopted to the reactor building in spite of the containment vessel applied for HTTR, in order to achieve economy of the reactor construction. Therefore, in case of GTHTR300 fuel, as-fabricated fuel failure fraction is limited below $5 \times 10^{-4}$ how is less than $0.2 \%$ of the HTTR and is determined based on experiences of HTTR first-loading fuel fabrication. As-fabricated fuel failure fractions for HTR50S and HPC HTGR are not be published yet, however, would be limited as same level as GTHTR300 fuel.

In addition, JAEA's designing HTGRs employing the high burnup fuel except for HTTR takes additionally a systematic fuel failure mode, a failure by the internal gas pressure, into consideration as described below. 


\subsection{Failure modes of TRISO-CFP}

For the safety design of HTTR fuel, two systematic failure modes are taken into consideration (Saito, 1994); kernel migration (Lindemer, 1974) and corrosion of SiC coating by palladium (Minato, 1990). On the other hand, it is known that $\mathrm{UO}_{2}$-TRISO CFP shall be failed by increasing internal pressure of TRISO due to carbon monoxide (CO) gas and fission gases generated by fission. Under high burnup over $100 \mathrm{GWd} / \mathrm{t}$, internal pressure failure becomes dominant, although this failure mode was not applied for HTTR fuel because of its lower burnup, $33 \mathrm{GWd} / \mathrm{t}$ in maximum.

Therefore, in the safety design of HTR50S, HPC HTGR and GTHTR300's TRISO-CFPs, the following tendencies are seen;

- $\quad$ Smaller diameter of $\mathrm{UO}_{2}$ fuel kernel and thicker buffer layer to reduce internal gas pressure.

- $\quad$ Thicker SiC coating layer to increase integrity of TRISO as a pressure vessel.

\section{Upgrading HTGR fuel technologies for high burnup \\ 3.1 Upgraded method for HTGR fuel design 3.1.1 Design for TRISO-CFP}

The reference specification of the upgraded TRISO-CFP, in case of EBU TRISO-CFP, have been determined according to the following requirements (Ueta, 2016):

- $\quad$ The diameter of the new TRISO CFP was determined to be same as the HTTR, because of minimizing fuel failure fraction in the HTTR fuel compaction condition and keeping accuracies in fuel compact inspections.

- The diameter of $\mathrm{UO}_{2}$ kernel was determined to be smaller than that of the HTTR in order to increase the volume of buffer layer for avoiding the pressure vessel failure of the CFP. A reference diameter of $500 \mu \mathrm{m}$ for EBU TRISO-CFP was settled considering the fuel kernel fabrication process and an experience on $550 \mu \mathrm{m}$ kernel fabrication (Sawa, 2003).

- $\quad$ The thickness of buffer layer was determined to be larger than that of the HTTR. In order to avoid two modes of failures due to amoeba effect (Lindemer, 1974) and to the internal gas pressure.

- $\quad$ The thickness of SiC layer shall be increased to enhance the integrity of TRISO CFP as the pressure vessel. It was determined to be larger than that of the HTTR considering the fuel kernel fabrication process and an experience on $35 \mu \mathrm{m}$ thick fabrication (Sawa, 2003).

- $\quad$ Each IPyC and OPyC layer is coated with similar thickness to the HTTR to maintain isotropic quality by the fabrication.

To evaluate failure probability of the above TRISO-CFP due to internal gas pressure under the irradiation, JAEA has developed the calculation codes such as FIGHT (Sawa, 1996) and Code-B-2 (Aihara, 2013). The essential features of both fuel failure models are based on the followings (Sawa, 1996);

- $\quad$ The model calculates failure probability of each coating layer.

- The failure probability of each coating layer is described by a Weibull distribution with microscopic surface flaws considered to be critical failure initiation sites. The failure criterion of each coating layer is determined based on experimental observations accumulated from irradiation tests.

- $\quad$ The stresses act on the coating layers of the fuel particle are assumed to be caused by pressure of fission gases and $\mathrm{CO}$ gas from $\mathrm{UO}_{2}$ kernel and by fast neutron-induced shrinkage of the PyC layers (CO generates by excess oxygen liberated during fissioning of $\mathrm{UO}_{2}$ reacting with carbonaceous buffer coating.). The maximum stress is evaluated by rigid SiC model with spherical shell because recently fabricated fuel particles have good sphericity.

- $\quad$ Two types of failed particles are categorized, i.e., through-coatings failed particle and SiC-failed particle. The through-coatings failed particle results from IPyC, SiC and OPyC layer failure (i.e., an exposed fuel kernel). The SiC-failed particle has failed IPyC and SiC layers but an intact OPyC layer. The gaseous fission products are released from through-coatings failed particle. On the other hand, since OPyC layer can retain the gaseous fission products, the SiC-failed particle does not release the gaseous fission products. The failure probability that an as-fabricated SiC-failed particle becomes a through-coatings failed particle is also modeled.

The fracture strength distribution of coating layers is expressed by a Weibull distribution. The failure probability of each layer is calculated by the following basic equation; 


$$
f_{i}(t)=1-\exp \left(-\ln 2 \times\left(\frac{\sigma_{i}(t)}{\sigma_{0, i}}\right)^{m_{i}}\right)
$$

where, $f_{i}(t)$ is failure probability of i-layer at irradiation time t, $\sigma_{i}(t)$ is stress on the i-layer at irradiation time $\mathrm{t}(\mathrm{MPa})$, $\sigma_{0, i}$ is strength of the i-layer (MPa) and $m_{i}$ is Weibull modulus for the i-layer strength.

The tensile stress is introduced into the coatings due to the pressure of fission gases and CO gas as burnup proceeds. On the other hand, the IPyC and OPyC layers undergo irradiation-induced shrinkage as a result of fast neutron exposures. Consequently, the OPyC layer places a compressive load on the SiC layer, which counteracts the SiC tensile stress due to internal pressure. Similarly, the IPyC layer acts to reduce the SiC tensile stress by tending to contract while bonded to inner SiC surface. The shrinkage of the PyC layers puts them into tension. Based on the above behavior, failure probability of coating layer is modeled as follows;

- $\quad$ The SiC layer fails by internal gas pressure in high burnup irradiation condition. The compressive stress caused by the IPyC and the OPyC layers shrinkage mitigates the stress on the SiC layer. When the OPyC layer is intact, the failure probability of the SiC layer $\left(f_{S i C}\right)$ is evaluated based on tensile stress which is a balance of the stress due to internal gas pressure and the compressive stresses by both the IPyC and the OPyC shrinkage.

- The OPyC layer fails only by tensile stress. When the SiC layer, which is inside of the OPyC layer, is intact, the failure of the OPyC does not occur $\left(f_{O P y C}^{\prime}=0\right)$ because it is supported by the stronger SiC layer. In the $\mathrm{SiC}$ failed particle, the failure of the OPyC layer occurs by the internal gas pressure $\left(f_{\text {OPyC }}^{\prime}\right)$.

- $\quad$ Based on above-mentioned failure behavior, probability that the intact particle becomes the through-coatings failed particle $\left(F_{T C}\right)$ can be expressed as the followings;

$F_{T C}=f_{I P y C}^{\prime} \times f_{\text {SiC }} \times f_{O P y C}^{\prime}$

Figure 1 shows the relationship between dimensions of buffer layer, SiC layer and fuel kernel of each TRISO-CFP and the probability to lose its intactness against the pressure vessel failure at the burnup of $120 \mathrm{GWd} /$ thm for instance. In this calculation, the failure probability of CFP was settled at $1 \times 10^{-6}$, and other calculation conditions were as follows; $1300{ }^{\circ} \mathrm{C}$ of irradiation temperature, 1,460 effective full power days (EFPDs) and $3.3 \times 10^{25} \mathrm{~m}^{-2}$ of fast neutron fluence $(\mathrm{E}>29 \mathrm{fJ})$. Regardless of original specification of every type of CFP, it was assumed that the corresponding amount of uranium-235 was loaded and burned by fission to $120 \mathrm{GWd} /$ thm in order to make the same internal gas generating condition. Each dotted line in the figure shows a boundary of probability at $1 \times 10^{-6}$ for each SiC layer thick.

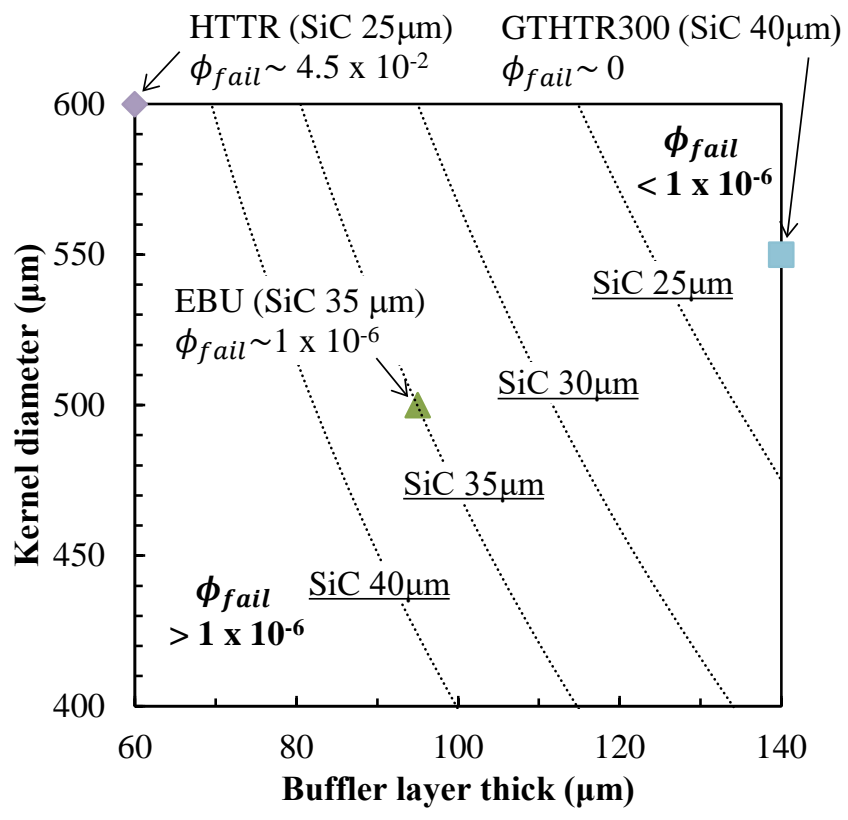

Fig. 1 Relationships between kernel diameter, buffer layer thick and $1 \times 10^{-6}$ of failure probability $\left(\phi_{\text {fail }}\right)$ at $1300{ }^{\circ} \mathrm{C}$ and $120 \mathrm{GWd}$ /thm for HTTR, EBU and GTHTR300 types TRISO-CFPs. 
As the result of the fabrication, EBU type TRISO-CFP keeps intactness with the failure probability at $1 \times 10^{-6}$, and GTHTR300 type would not fail in this irradiation condition. HTTR type would fail with higher probability than others in this irradiation condition since it was designed for use with the burnup up to $33 \mathrm{GWd} / \mathrm{thm}$.

\subsubsection{Design for fuel rod}

The conventional fuel rod applied for HTTR consists of fuel compact and graphite sleeve. This sleeve works to prevent oxidation of the fuel compact from impurities in the primary coolant under normal operation, and from oxygen and/or humidity under the air/water-ingress accident (concentric hot gas duct ruptured accident). On the other hand, the gap distance between outer surface of fuel compact and inner surface of the sleeve increases during the irradiation, because the shrinkage rate of fuel compact matrix by fast neutron is larger than that of graphite (Fukuda, 1989). Then, the difference of temperature due to this gap would become around $90{ }^{\circ} \mathrm{C}$ in case of the HTTR (Tobita, 1990), which could cause to decrease the fuel temperature as the design limit. Therefore, HPC HTGR and GTHTR300 fuel employ the monolithic fuel rod, which has a thin scale made of same material as fuel compact matrix on the surface of fuel compact in spite of the sleeve to enhance the heat removal and to decrease fuel temperature.

For compaction, two kinds of fuel compact matrix were studied in this study; one was the conventional HTTR's A33 matrix which is a mixture of $64 \mathrm{wt} \%$ of natural graphite, $16 \mathrm{wt} \%$ of petroleum graphite and $20 \mathrm{wt} \%$ of phenol resin supplied by Nuclear Fuel Industries (NFI), Ltd.; the value means weight percent before carbonization. Another consisted of newly-chosen natural- and petroleum-graphite powders supplied by Japanese graphite fabricators and the conventional binder, of which the weight ratio was as same as the HTTR's. Each new graphite powder was selected according to properties of conventional powders used for HTTR. Table 2 shows the focused property of each graphite matrix material in this study.

Results of testing fabrication of fuel compact with each graphite matrix material are shown in Fig. 2. Properties and characterization of each graphite matrix material should be investigated in detail, however in this study, it was found that the graphite matrix composing of NG-B and PG-A performed better agreement with the conventional one. Also, it is suggested that grain size distribution of natural graphite could significantly influence on geometry and density of fuel compact, because NG-B's grain size was the same level as the conventional one's, and was smaller than NG-A's. Finally, composition of NG-B and PG-A was selected as a candidate of new graphite matrix material, and its irradiation property was studied through an irradiation test as described below.

Table 2 Properties of graphite matrix materials chosen in this study.

\begin{tabular}{c|c|c}
\hline & Density & $\begin{array}{c}\text { Percentage of } \\
\text { grain size less } \\
\text { than } 75 \text { microns }\end{array}$ \\
\hline $\begin{array}{c}\text { Specifications } \\
\text { Natural graphite }\end{array}$ & $2.2 \pm 0.1$ & $>95$ \\
NG-O & 2.26 & $>97.3$ \\
NG-A & 2.25 & $>85.0$ \\
NG-B & 2.25 & $>99.7$ \\
Petroleum graphite & & $>97.0$ \\
PG-O & 2.14 & $>95.9$ \\
PG-A & 2.26 & \\
\hline
\end{tabular}

* Nomenclature; NG-O and PG-O are the A3-3 material used for the HTTR fuel compact. 

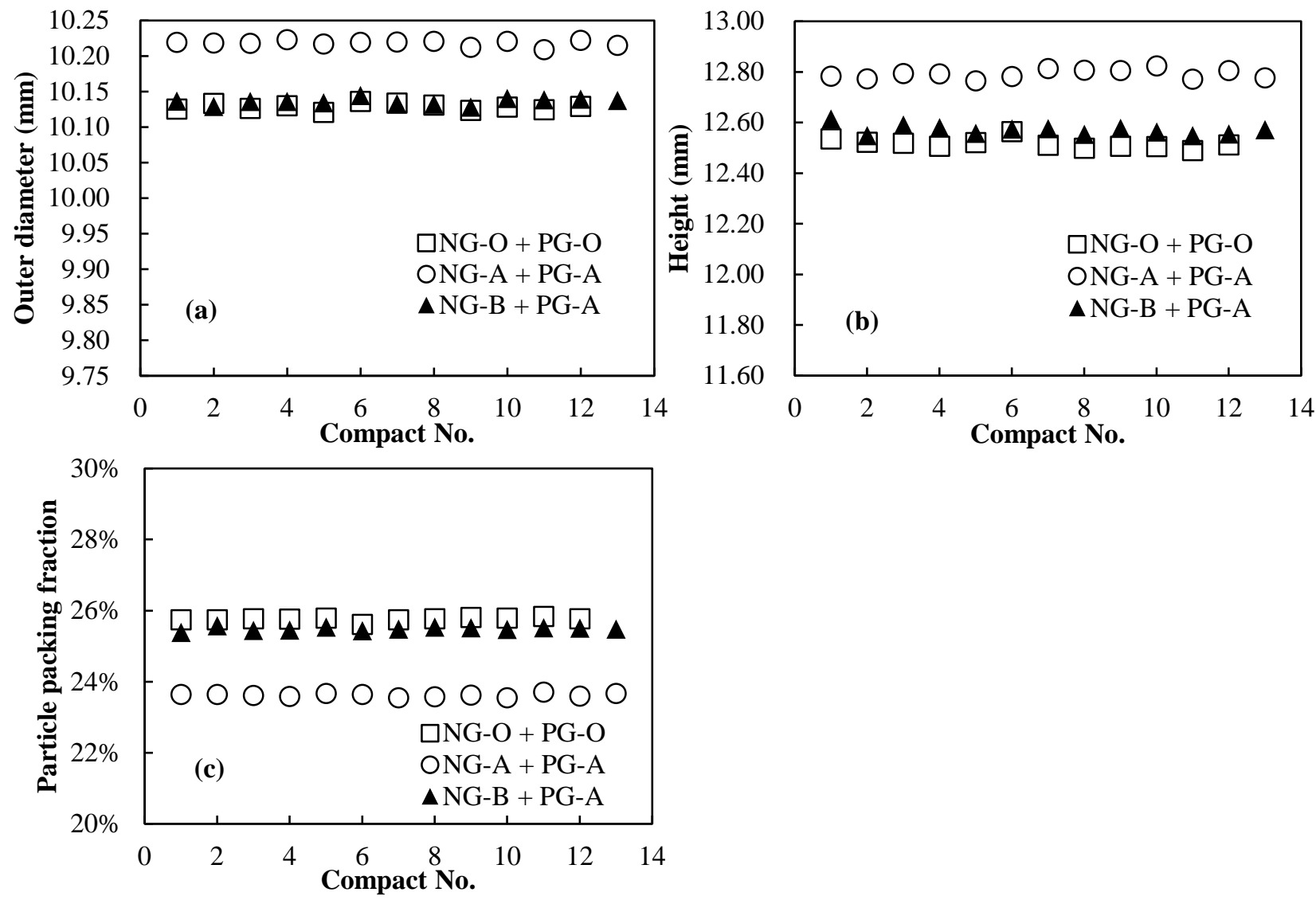

Fig. 2 (a)Outer diameter, (b)height and (c)particle packing fraction of fuel compact fabricated with each graphite matrix.

\subsection{Demonstration test of high burnup HTGR fuel}

As the latest results on the high burnup HTGR fuel progressing in a framework of International Science and Technology Centre (ISTC) regular project in Kazakhstan, irradiation properties of the fuel compact including the EBU TRISO-CFP fabricated in Japan at the burnup around $100 \mathrm{GWd} / \mathrm{thm}$ are being investigated (Ueta, 2016 and Shaimerdenov, 2018).

\subsubsection{Irradiation performance of the EBU TRISO-CFP (Ueta, 2016)}

The EBU TRISO-CFP has been fabricated based on HTTR fuel technology and irradiated up to $100 \mathrm{GWd} / \mathrm{thm}$ in target. As the result of the fabrication, dimensions of newly designed CFP including the tolerance was within the failure probability of $1 \times 10^{-6}$ as shown in Fig. 3, and it was suggested that the new CFP could fabricated successfully to maintain its intactness at $100 \mathrm{GWd} /$ thm even if considering the fabrication tolerance.

The irradiation test with the high burnup fuel has performed in the irradiation conditions at $1.0 \times 10^{18} \mathrm{~m}^{-2} \mathrm{~s}^{-1}$ of thermal neutron flux and at $1,050 \pm 100{ }^{\circ} \mathrm{C}$ of the target irradiation temperature corresponding to the HTGR normal operating condition. Finally, it took for 403 EFPDs of irradiation duration and the calculated level of burnup has comprised about $94 \mathrm{GWd} / \mathrm{t}$ to the end of irradiation. Temperature of the fuel compacts reached at $1,190{ }^{\circ} \mathrm{C}$ in maximum during the irradiation. Release rate to birth rate ratio (R/B) of ${ }^{88} \mathrm{Kr}$ indicated that two TRISO CFPs in three fuel compacts were failed additionally during the irradiation, which was less than the number of as-fabricated SiC-defective TRISO-CFP, i.e., 1 failure in each fuel compact. 


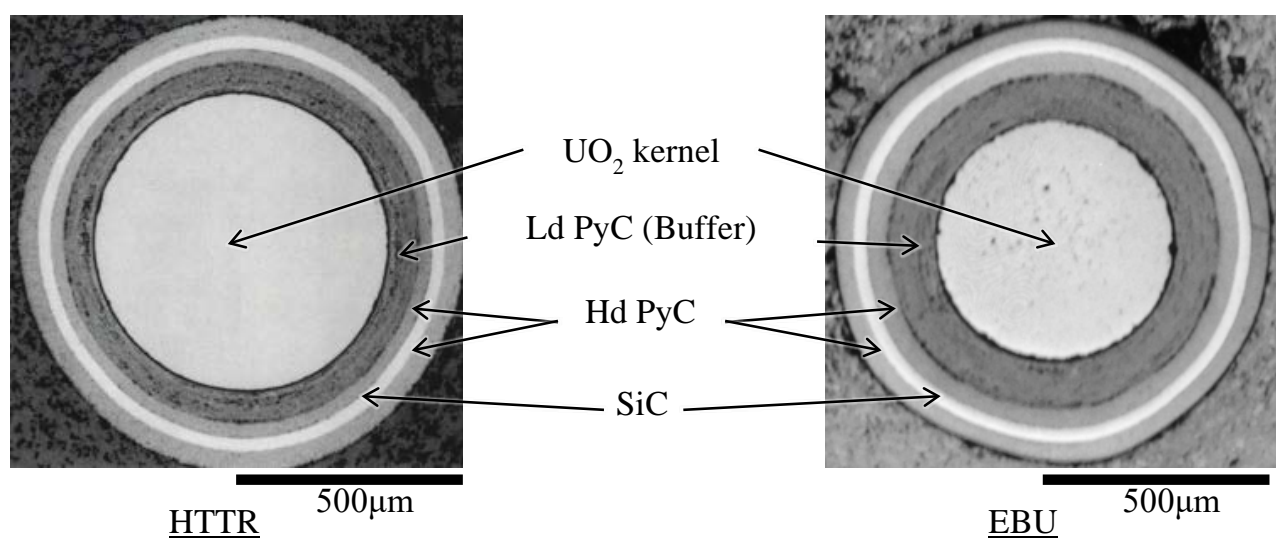

Fig. 3 Cross sections of HTTR and EBU TRISO-CFPs.

\subsubsection{Irradiation performance of fuel compact matrix}

It is known that the dimensional shrinkage of a fuel compact is varied depending on the fast neutron fluence ( $\mathrm{E}>29$ $\mathrm{fJ})$, which is almost linearly increased at the beginning of irradiation $\left(\sim 1.5 \times 10^{25} \mathrm{~m}^{-2}\right)$ and gradually decreased after that up to $3 \times 10^{25} \mathrm{~m}^{-2}$ following the approximate equation described typically as the secondary expression (Fukuda, 1989). Also, an experimental data indicated that almost no influence on the fuel compact shrinkage was observed in the temperature range from 800 to $1,700{ }^{\circ} \mathrm{C}$ (Fukuda, 1989). It is important to extend irradiation data of fuel compact to the condition for the practical use over $3 \times 10^{25} \mathrm{~m}^{-2}(\mathrm{E}>29 \mathrm{fJ})$.

PIEs with irradiated fuel compacts have been carried out by the INP RK under new ISTC regular project since May 2017 to May 2019 (Shaimerdenov, 2018). As a non-destructive test with irradiated fuel compact, irradiation shrinkage rate as a function of fast neutron fluence was evaluated as show in Fig.4. Each dimension of the fuel compact before and after irradiation were measured by micrometer. As a comparison, the figure shows the data of the 94F-9A capsule irradiated with the HTTR first-loading fuel up to $60 \mathrm{GWd}$ /thm (Ueta, 2007) and of the 91F-1A capsule with high burnup type HTTR TRISO-CFP up to $90 \mathrm{GWd}$ /thm (Sawa, 2001) in Japan Material Testing Reactor (JMTR). As the result, shrinkage rate of fuel compact using conventional matrix material shows good agreement with data obtained in the HTTR

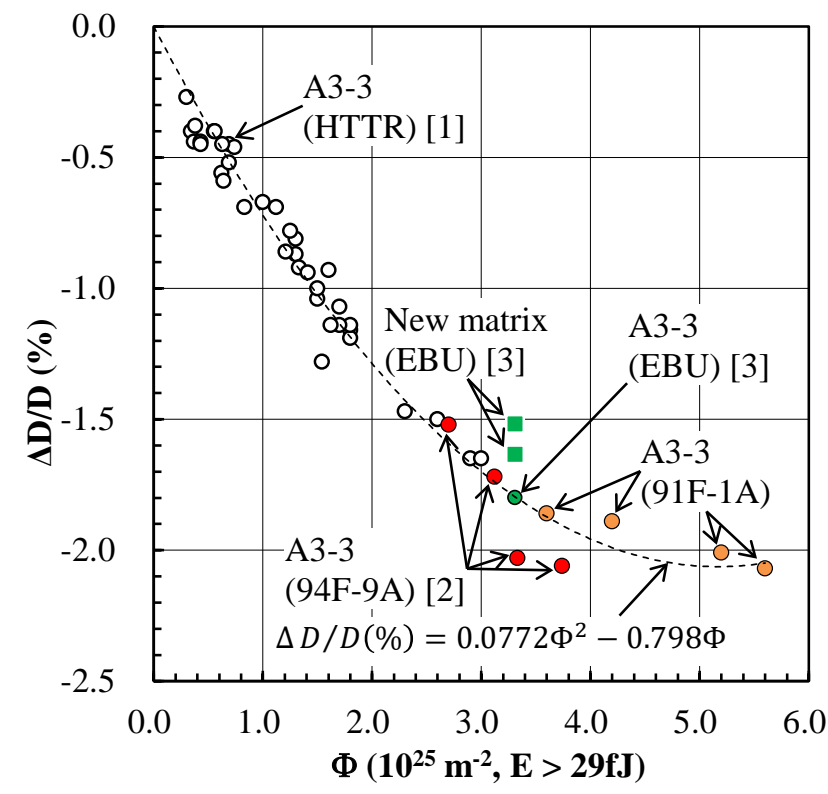

Fig. 4 Irradiation shrinkage rate of fuel compact as a function of fast neutron fluence. References; [1] Fukuda, 1989, [2] Ueta, 2007 and [3] Shaimerdenov, 2018. 
project. Also, the fuel compacts using new graphite matrix (composition of NG-B and PG-A in Table 2 as mentioned above) performed good tendency of shrinkage by irradiation. More to say, new graphite matrix showed less shrinkage for neutron irradiation compared with the conventional graphite matrix. Further characterization of the graphite matrix is needed to reveal this reason; however, it is guessed that one of key parameters could be the high percentage of graphite grain size less than $1 \mu \mathrm{m}$.

Finally, an equation of shrinkage rate of fuel compact matrix up to $6 \times 10^{25} \mathrm{~m}^{-2}$ of fast neutron fluence (E $>29 \mathrm{fJ}$ ) was determined as the following;

$$
\Delta D / D(\%)=0.0772 \Phi^{2}-0.798 \Phi
$$

where, $\Delta D / D$ is volumetric percent of shrinkage rate of fuel compact under the irradiation and $\Phi$ is fast neutron fluence $\left(10^{25} \mathrm{~m}^{-2}, \mathrm{E}>29 \mathrm{fJ}\right)$.

This data will contribute to the future thermal-hydraulics designs not only for HTR50S adopting the pin-in-block type fuel element with graphite sleeve, but also for GTHTR300 with the monolithic type graphite-matrixed fuel element.

\section{Future $R \& D$ plan on the high burnup fuel 4.1 Characterization of new graphite matrix}

As a result of this study, it was demonstrated that new graphite matrix shows good performance by neutron irradiation around $3.3 \times 10^{25} \mathrm{~m}^{-2}(\mathrm{E}>29 \mathrm{fJ})$. For its practical use, further irradiation data should be accumulated. Also, characterization of graphite matrix should be needed such as mechanical properties (density, grain size distribution, graphitization degree, impurities, viscosity, etc.), parameters of overcoating and compaction process (temperature, pressing velocity, pressure, etc.).

\subsection{Other requirements for the high burnup HTGR fuel}

As a result of the irradiation test in this study, fuel compacts have attained at the temperature up to $1,250{ }^{\circ} \mathrm{C}$ during the irradiation. This level of fuel irradiation temperature is low comparing with one in the past qualification tests of the HTTR fuel which suppose normal operating condition, generally at $1,300^{\circ} \mathrm{C}$ in target. On the other hand, it can be said that this temperature level is as same as that proposed to the recent qualification of the TRISO fuel for VHTR in normal operating condition (OECD, 2012). One of the reasons could be that the range of VHTR's core outlet temperatures tends to extend in lower side, between 700 and $950{ }^{\circ} \mathrm{C}$ (OECD, 2012), in comparison with the HTTR's between 850 to $950{ }^{\circ} \mathrm{C}$ (Saito, 1994). However, additional irradiation tests supposing off-normal condition up to $1,600{ }^{\circ} \mathrm{C}$ will be needed in future to construct database in terms of the systematic fuel failure modes, i.e., kernel migration and Pd-SiC (Saito, 1994), which will be required in the fuel safety for the commercialized HTGRs concepted by JAEA.

In addition, although HTGR attains higher burnup in accordance to the upgraded fuel technologies mentioned above, the amount of uranium loaded in the reactor core decreases due to adopting smaller fuel kernel. For the countermeasure, technologies to increase particle packing fraction in the fuel compact are being developed in worldwide.

JAEA has confirmed that a conventional overcoating method by HTTR fuel technology can achieve up to around 33 volumetric percent with keeping less than HTTR fuel design limit, $8 \times 10^{-5}$ of as-fabricated SiC-defective fraction (Mizuta, 2017). As a latest overcoating technology in USA, well-qualified compaction technologies with graphite matrix is being developed over 40 volumetric percent in target and 37 volumetric percent as the current status (Petti, 2017). On the contrary, in case of applying the high burnup TRISO-CFP for the HTTR core, packing fraction around $45 \%$ shall be needed to satisfy the required uranium mass, approximately 13.5 grams of uranium per a fuel compact. Therefore, new advanced technologies to adopt larger fuel kernel or to reduce systematic fuel failure due to internal gas pressure by fission should be required, which could contribute to extending lifetime of the fuel because of increase of the amount of uranium loaded in the reactor without increasing not only fissile enrichment but also particle packing fraction of fuel compact.

UCO TRISO-CFP is one of candidates to prevent from the failure due to internal gas pressure (Petti, 2017). This is being established in worldwide, however, its fabrication technology and its irradiation properties might not be matured comparing with those of $\mathrm{UO}_{2}$ TRISO-CFP, especially in Japan.

On the other hand, zirconium carbide $(\mathrm{ZrC})$-coated-UO $\mathrm{UO}_{2}$ TRISO-CFP would have a strong potential to achieve 
extremely high burnup using $\mathrm{UO}_{2}$ fuel kernel (Bullock, 1983). Through R\&Ds on fabrication technologies of the 3STRISO-CFP, it was evaluated that a $\mathrm{ZrC}$ coating with $10 \mu \mathrm{m}$ thick on $\mathrm{PuO}_{2}$-YSZ kernel with a diameter of $400 \mu \mathrm{m}$ can get oxygen generated by fission at the burnup of $600 \mathrm{GWd} / \mathrm{t}$ of ${ }^{239} \mathrm{Pu}$ metal (Goto, 2018). In addition, fabrication technologies of both $\mathrm{UO}_{2}$ TRISO-CFP and ZrC coating by the bromide process has been well-established by NFI, Ltd. and JAEA, respectively (Ueta, 2008). Figure 5 shows an example of ZrC and TRISO coatings on dummy kernel which was demonstrated in R\&D on 3S-TRISO. On the contrary, there might be a possibility to generate a hazardous reactant, such as a certain deliquescent bromide, for both $\mathrm{UO}_{2}$ and $\mathrm{ZrC}$ during the $\mathrm{ZrC}$ coating process. A chemical influence

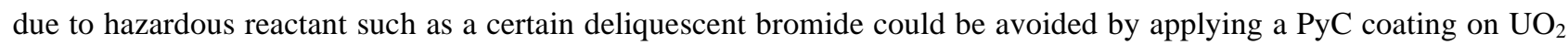
kernel before $\mathrm{ZrC}$ coating based on the 3S-TRISO technology (Ueta, 2018). Therefore, the following R\&D items will be needed to establish $\mathrm{ZrC}$-coated $\mathrm{UO}_{2}$ TRISO-CFP;

1) Establishing continuous PyC-ZrC-TRISO coating technology using actual $\mathrm{UO}_{2}$ fuel kernel;

2) Conducting irradiation tests and PIEs to demonstrate the integrity against systematic failure mechanisms, i.e., failures due to internal gas pressure, kernel migration effect and Pd-SiC reaction;

3) Developing the FP release model and the fuel performance models for systematic failure mechanisms.

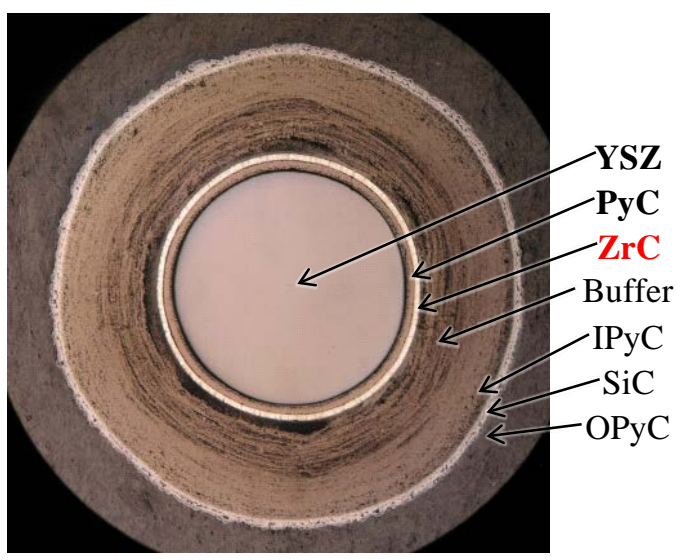

Fig. 5 An example of the ZrC-coated TRISO-CFP demonstrated by JAEA (ZrC coating on YSZ surrogating $\mathrm{UO}_{2}$ ) and NFI, Ltd. (TRISO coatings).

\section{Conclusions}

This paper described design principles and specifications of so-called "the high burnup fuels" for HTR50S and HPC HTGR as small-type practical HTGRs, GTHTR300 as VHTR and Pu-burner HTGR developed by JAEA. The high burnup fuel consists of the upgraded TRISO-CFP for high burnup use, and the fuel compacts with two kinds of graphite matrices, the conventional and the newly-developed ones.

For upgrading the design method of TRISO-CFP for enhancing economy of the HTGR, its failure probability was evaluated by so-called the internal gas pressure failure model. To demonstrate the integrity of the EBU TRISO-CFP and irradiation performance of fuel compact matrix, irradiation tests and PIEs were conducted under not only domestic projects but also international collaborations with Kazakhstan in a frame of ISTC regular project. As the latest result, the EBU TRISO-CFP was demonstrated its integrity at the burnup nearly $100 \mathrm{GWd} /$ thm successfully, how is three to four times higher than that of the HTTR fuel (33 GWd/thm). In addition, through the PIEs, the extended data of shrinkage rates of A3-3 and newly-selected graphite matrices for the fuel compact as a function of fast neutron fluence over $5 \times$ $10^{25} \mathrm{~m}^{-2}$ (E > $29 \mathrm{fJ}$ ) was obtained successfully, which will contribute to the future thermal-hydraulics designs of the HTGR core using graphite matrix.

Furthermore, as the future R\&Ds needed for the high burnup HTGR fuel, adoption of larger fuel kernel could be essential to extend lifetime of the fuel instead of increasing not only fissile enrichment but also particle packing fraction of fuel compact. As one of candidates for the advanced high burnup fuel, $\mathrm{ZrC}$ coated $\mathrm{UO}_{2}$ TRISO-CFP would have a strong potential to extend burnup.

Other advanced TRISO-CFP concepts under development include SiC-matrix fuel to essentially eliminate oxidationrelated failure mechanisms during severe accidents and provide even higher levels of defense-in-depth and inherent 
safety. Both Japan and the U.S. have been developing this concept, which could provide an opportunity for international collaboration on a truly accident-tolerant nuclear fuel.

\section{Acknowledgements}

This paper involves the result of the "Development of Security and Safety Fuel for Pu-burner HTGR" which was conducted as the project of Japanese Ministry, MEXT. Authors also acknowledge to engineers of Nuclear Fuel Industries, Ltd. for their support by testing fabrication of fuel compact.

\section{References}

Aihara, J., Ohashi, H., Sawa, K. and Tachibana, Y., Code-B-2 for stress calculation for SiC-TRISO fuel particle, JAEAData/Code 2012-030 (2013), pp.1-13 (in Japanese).

Bullock, R.E. and Kaae, J.L., Performance of coated $\mathrm{UO}_{2}$ particles gettered with ZrC, J. Nucl. Mater. Vol.115, No.1 (1983), pp.69-83.

Fukaya, Y., Goto, M., Ohashi, H., Tachibana, Y., Kunitomi, K. and Chiba, S., Proposal of a plutonium burner system based on HTGR with high proliferation resistance, J. Nucl. Sci. Technol., Vol.51 (2014), pp.818-831.

Fukaya, Y., Mizuta, N., Goto, M., Ohashi, H., and Yan, X.L, Conceptual Design Study of a High Performance Commercial HTGR, Proceedings of the 9th International Topical Meeting on High Temperature Reactor Technology (HTR2018) (2018), Paper No. HTR2018-101, pp.1-7.

Fukuda, K., Ogata, T., Kashimura, S., Hayashi, K., Tobita, T., Kobayashi, F., Minato, K., Kikuchi, H, Murakami, H., Ikawa, K. and Iwamoto, K., Research and development of HTGR fuels, JAERI-M 89-007 (1989), pp.1-603 (in Japanese).

Goto, M., Study on Nuclear Analysis Method for High Temperature Gas-cooled Reactor and Its Nuclear Design (Thesis), JAEA-Review 2014-058 (2014), pp.1-103 (in Japanese).

Goto, M., Aihara, J., Inaba, Y., Ueta, S., Fukaya, Y. and Okamoto, K., Study on Pu-burner High Temperature Gas-cooled Reactor in Japan - Design Study of Fuel and Reactor Core -, Proceedings of . 9th International Topical Meeting on High Temperature Reactor Technology (HTR2018) (2018), Paper No. HTR2018-91, pp.1-6.

Hayashi, K., Sawa, K., Shiozawa, S. and Fukuda, K., Assessment of integrity of High Temperature Engineering Test Reactor (HTTR) and its permissible design limit, JAERI-M 89-162 (1989), pp.1-83 (in Japanese).

Howard, R.M., Price, M.S.T. and Shepard, L.R., A summary and evaluation of the achievements of the Dragon Project and its contribution to the development of the high temperature reactor, Dragon Project Report DP-1000 (1978).

Katanishi, S., Takei, M., Nakata, T. and Kunitomi, K., Feasibility Study on High Burnup Fuel for Gas Turbine High Temperature Reactor (GTHTR300), (II), Transactions of the Atomic Energy Society of Japan, Vol. 3, No. 1 (2004), pp.67-75 (in Japanese).

Kuramoto, K., Nitani, N. and Yamashita, T., Durability test on irradiated rock-like fuels, J. Nucl. Mater., Vol.319 (2003), pp.180-187.

Lindemer, T. B. and Olstad, R.A., Htgr Fuel Kernel Migration Data for the TH-U-C-O System as of April 1, 1974, ORNLTM-4493 (1974), pp.1-59.

Minato, K., Ogata, T., Kashimura, S., Fukuda, K., Shimizu, M., Tayama, Y. and Takahashi, I., Fission product palladiumsilicon carbide interaction in HTGR fuel particles, J. Nucl. Mater. Vol.172, Issue 2 (1990), pp.184-196.

Minato, K., Kikuchi, H., Tobita, T., Fukuda, K., Kaneko, M., Suzuki, N., Yoshimuta, S. and Tomimoto, H., Improvements in quality of as-manufactured fuels for high-temperature gas-cooled reactors, J. Nucl. Sci. Technol. Vol.34, No. 3 (1997), pp.325-333.

Mizuta, N., Ueta, S., Aihara, J. Shibata, T., Confirmation of feasibility of fabrication technology and characterization of high-packing fraction fuel compact for HTGR, JAEA-Technology 2017-004 (2017), pp.1-22 (in Japanese).

Mizuta, N., Aoki, T., Ueta, S., Ohashi, H., Yan, X.L., Study of SiC-matrix fuel element for HTGR, Proceedings of the 27th International Conference on Nuclear Engineering (ICONE-27) (2019), Paper No. ICONE27-2157, pp.1-5.

OECD Nuclear Energy Agency, 2012, Technology Roadmap Update for Generation IV Nuclear Energy Systems, URL<https://www.gen-4.org/gif/upload/docs/application/pdf/2014-03/gif-tru2014.pdf>, (accessed on 27 June, 2019). 
Ohashi, H., Sato, H., Tazawa, Y., Yan, X.L, Tachibana., Y. and Kunitomi, K., Conceptual design of small-sized HTGR system for steam supply and electricity generation (HTR50S), Proceedings of ASME 2011 Small Modular Reactors Symposium (SMR 2011) (2011), Paper No. SMR2011-6558, pp. 51-60.

Okamoto, K., Ohashi, K., Ohiara, K. and Kunitomi, K., Study on Pu-burner high temperature gas-cooled reactor in Japan (1) Concept, Proceedings of the 9th International Topical Meeting on High Temperature Reactor Technology (HTR2018) (2018), Paper HTR2018-64.

Petti, D.A., A Summary of the Results from the DOE Advanced Gas Reactor (AGR) Fuel Development and Qualification Program, INL/EXT-16-40784 (2017).

Saito, S., Tanaka, T., Sudo, Y., Baba, O., Shindo, M., Shiozawa, S., Motegi, H., Okubo, M., Ito, N., Shindo, R., Kobayashi, F., Kurihara, R., Hayashi, K., Hada, K., Kurata, Y., Yamashita, K., Kawasaki, K., Iyoku, T., Kunitomi, K., Maruyama, S., et al., Design of High Temperature Engineering Test Reactor (HTTR), JAERI-1332 (1994).

Sawa, K., Shiozawa, S., Minato, K. and Fukuda, K., Development of a coated fuel particle failure model under high burnup irradiation, J. Nucl. Sci. Technol., Vol. 33 (1996), pp.712-720.

Sawa, K., Tobita, T., Mogi, H., Shiozawa, S., Yoshimuta, S., Suzuki, S. and Deushi K., Fabrication of the first-loading fuel of the High Temperature Engineering Test Reactor, J. Nucl. Sci. Technol. Vol.36, No.8 (1999), pp.683-690.

Sawa, K., Tobita, T., Takahashi, M., Saito, T., Iimura, K., Yokouchi, I, Serizawa, H., Sekino, H. and Ishikawa, A., Irradiation test of high burnup coated fuel particles for High Temperature Gas-cooled Reactor; 91F-1A Sweap gas capsule irradiation test, JAERI-Research 2001-043 (2001) (in Japanese).

Sawa, K. and Tobita, T., Investigation of irradiation behavior of SiC-coated fuel particle at extended burnup, Nucl. Technol. Vol. 142 (2003), pp.250-259.

Shaimerdenov, A., Gizatulin, S., Kenzhin, Y., Dyussambayev, D., Ueta, S., Aihara, J. and Shibata, T., Investigation of Irradiated Properties of Extended Burnup TRISO Fuel, Proceedings of the 9th International Topical Meeting on High Temperature Reactor Technology (HTR2018) (2018), Paper HTR2018-182.

Tobita, T. and Fukuda, K., Development of advanced HTGR fuel, 1; Fabrication test and some characteristics of monolithic fuel rod, JAERI-M 90-136 (1990) (in Japanese).

Ueta, S., Umeda, M., Sawa, K., Sozawa, S., Shimizu, M., Ishigaki, Y. and Obata H., Preliminary Test Results for Post Irradiation Examination on the HTTR Fuel, J. Nucl. Sci. Technol. Vol.44, No.8 (2007), pp.1081-1088.

Ueta, S., Aihara, J., Yasuda, A., Ishibashi, H., Takayama, T. and Sawa, K., Fabrication of uniform ZrC coating layer for the very high temperature reactor fuel, J. Nucl. Mater. Vol.376, No.2 (2008), pp.146-151.

Ueta, S., Aihara, J., Sawa, K., Yasuda, A., Honda, M. and Furihara, N., Development of high temperature gas-cooled reactor (HTGR) fuel in Japan, Prog. Nucl. Energy, Vol.53 (2011), pp.788-793.

Ueta, S., Mizuta, N., Sasaki, K., Sakaba, N., Ohashi, H. and Yan, X.L., Irradiation test and post irradiation examination of the high burnup HTGR fuel, Proceedings of the 8th International Topical Meeting on High Temperature Reactor Technology (HTR2016) (2016), Paper No. HTR2016-18491, pp.246-252.

Ueta, S., Aihara, J., Mizuta, N., Goto, M., Fukaya, Y., Tachibana, Y. and Okamoto, K., Study on Pu-burner High Temperature Gas-cooled Reactor in Japan - Test and characterization for ZrC coating -, Proceedings of the 9th International Topical Meeting on High Temperature Reactor Technology (HTR2018) (2018), Paper HTR2018-79.

Venneri, F., Katoh, Y. and Snead, L.L., Fully Ceramic Nuclear Fuel and Related Methods, United States Patent US 9,299,464 B2, March 29, 2016 (2016). 